\title{
Theoretical Discussion of the Financial Liberalization: The Political Economy of a Policy's Paradox
}

\author{
Benjamin García-Páez ${ }^{1}$ \\ ${ }^{1}$ Graduate Studies Department, Faculty of Economics, National Autonomous of Mexico University, Mexico \\ Correspondence: Benjamin García-Páez, Department of Graduate Studies, Room 116, Faculty of Economics, \\ National Autonomous of Mexico University (UNAM), Mexico City, 04510, Mexico. Tel: 52-56-222-170. E-mail: \\ Garpaez@servidor.unam.mx
}

$\begin{array}{lcc}\text { Received: April 16, } 2012 & \text { Accepted: May 13, } 2012 & \text { Published: July 1, } 2012 \\ \text { doi:10.5539/ijef.v4n7p33 } & \text { URL: http://dx.doi.org/10.5539/ijef.v4n7p33 }\end{array}$

\begin{abstract}
This paper argues the paradox that industrial countries and international financial organizationsrecommended less developed countries (LDCs) to reinforce their financial liberalization progressions. However, due to the current financial crisis, developed economies have to admit not taking the necessary policies themselves to circumvent the worst period of unbridled risk-taking by financial institutions. During the 1980s, industrialized economies feared LDCs fragile financial systems and their potential policy mismanagement given their lack of familiarity. Incongruously, markets have taken revenge on the "rentiers" and empirical evidence has shown that technocrats running the international financial system are also prone to big mistakes with adverse economic consequences.
\end{abstract}

Keywords: financial liberalization, economic growth, developing and industrial countries, banking system

\section{Background}

The current global financial crisis, which began with the US housing bubble burst in December 2007 but whose effects still are now being felt worldwide, has substantiated the need to put in place a new international system of regulation akin to the Breton Woods Conference afterWorld War II. Although the huge global growth and reach of financial systems meant that markets, economies and bank systems were increasingly interdependent, the need for better banking supervision had been recognized since the Asian market crisis in 1997 (Chang, 2000). Nevertheless, the world failed to set up an early warning system so that international monetary flows were properly monitored and countries were alerted from a crisis under development.

The paradox refers to the fact thatindustrial countries and international financial institutions advising less developed countries (LDCs) to strengthen their financial liberalization processes now have to admit not taking the necessary measures themselves to avoid the worst period of unbridled risk-taking by financial institutions. Industrialized economies fearedLDCs weak financial systems and potential policy mismanagement given the lack of experience in the 1980s.Ironically, markets have taken revenge on the rentiers and reality has shown that technocrats running the international financial system are also prone to big mistakes with adverse economic consequences (Palma, 2009).

As per the necessary reforms needed for the world economy's recovery, industrial countries have been advocating greater international policyregarding transparency and exposure. These procedures include ensuring national financial regulators stay in close touch with their counterparts in other countries and setting standards for financial institutions around the world on transparency and corporate governance. Also, reforming banker's pay and rewards to encourage responsible, long-term risk-taking rather than quick profit.

Since financial liberalization standsstill as a central policy prescription to LDCs almost along the same lines as when the neoliberal economic model was put forward approximately three decades ago, this paper returns to the so-called 'renewed' debate on financial liberalization which was in place in the 1980's just when the LDCs were being pressed by the main multilateral funding institutions, such as the International Monetary Fund (IMF) and the World Bank, to abandon their centrally controlled (repressed) systems and transform them into liberalized entities. For instance, in Latin America not only the financial reform but also the new development strategy as a whole was set up after a series of negative external and domestic shocks in the 1980s. Later on, when the Washington Consensus' set of first-best policies was implemented, the region did not put any resistance at all (Palma, 2010).

Afterwards, this discussion considers bank-lending behavior under risk situations. It also deals with more operative 
matters. This paper argues that financial markets are subject to implicit market imperfections because of the nature of the 'goods' they deal with. Credit is not a normal good, but a 'promise' of payment, which gives credit markets special characteristics.

\section{Theoretical Framework}

There are two main economic approaches to the nexus between financial development and overall economic growth and development: the prior-saving approach and the investment-led approach. The prior-saving approach argues that financial development encourages economic growth by increasing the amount of lendable funds, increasing credit, and thus increasing investment (McKinnon, 1973; Shaw, 1973). This model stresses the significance and necessityofrulesleading to increase saving levels, which would help find investment outlets (Thirlwall, 1989).

According to the complementary hypothesis between money and capital, potential investors must accumulate money balances prior to their investment expenditure (MacKinnon, 1973). In turn, money (broadly defined) accumulation is encouraged by higher rate of interest offered on deposits; so the money function can thus be expressed as a function of income, investment and the real interest rate. This approach also stressed the importance of a liberalized financial system as a means of increasing saving, investment and the productivity of investment. It strongly opposed any kind of government intervention in the financial system and criticized the argument that market forces do not work in LDCs (Shaw, 1973). In the investment-led approach, a post-Keynesian argument concerning the financial liberalization model is that investment is not supply determined but, on the contrary, the level of investment is what determines savings via the income multiplier effect (Burkett, 1991; Davidson, 1986; Dutt, 1991). They argue that high real interest rates negatively affect economic performance by discouraging both aggregate consumption and investment, therefore reducing the level of aggregate demand.

There is another approach, the Neo-Structuralist, which remains within the prior saving analytical framework. Its main criticism is confined to the argument that financial liberalization might reduce the amount of loanable funds for the whole financial system, including those of the 'curb' market, an unofficial money and capital market (World Bank, 1989). Although the discussion of the causality between financial development and economic growth still remains unsolved (Patrick, 1966; McKinnon 1988), most LDCs undertook a financial liberalization process in the 1980s and even early 1990s under prior-saving approach (World Bank, 1989).

LDCs were motivated by the need to increase the internal sources of finance but also appealed those looking to enlarge the role of the private sector in the economy. The underlying assumption is that the larger the reliance of the economy on the private sector, the greater the need for an efficient financial sector. The implications of this economic policy shift were clear and direct enough. LDCs had to direct their economic policy towards the liberalization of their financial sector in order to restrict the regulation imposed by the government on the financial system. It also encouraged the participation of the private sector and alloweda free operation of the market forces.

As established in the current literature, such an economic policy was not set up entirely due to Latin America's own volition but under the pressure caused by its sovereign debt crisis in the 1980s which, incidentally, almost brought the US financial system to its knees. Since loans to LDCs during 1982, accounted for more than twice the capital base of US banks, the crisis threatened to become a crisis for US financial crisis itself. The point is that both debtors and creditors are to be blamed for such a problem. On the one hand, the 1980s was a defining decade for Latin America because it saw many profligate countries shut out of the international markets and default after they took on unsustainable amount of debt. But, on the other hand, the debt crisis followed a sustained period of easy credit. In the late 1970's, the US and other Western European banks recycled abundant petrodollars through irresponsible loans to Latin American countries with limited conditionality.

As evidence, neither debtors nor creditors were prepared to manage the crisis, but what stands out is the turmoil inside the OECD governments and multilateral-financial institutions following the so called 'lost decade' of falling incomes in the region during the 1980's. On the one hand, although the loan syndication (as 500 banks were involved) was meant to reduce risk, it did not accomplish this goal. Additionally, the Federal Reserve chairman Paul Volker jacked up US interest rates to $20 \%$. A year later, Mexico announced it had nearly run out of reserves and could no longer service $\$ 80$ billion of foreign debt after the lenders refused to rollover short-term loans except at exorbitant rates. On the other hand, the initial answer to the Latin American debt crisis in 1982 was deemed to be economic growth, which would eventually allow countries to pay down debt. It was considered, that all they needed was the space to do so, via a series of official-emergency bailout packages.

It took several years to realize that deflating wages and shrinking economies were inconsistent with being able to fully pay off debts. What a first sight appeared to be a liquidity problem was an issue of solvency, as became clear in 1987 when Brazil said it would stop paying interest. Therefore, the answer was debt write-offs in 1989 under the Brady plan, which was designed to lessen these risks by gradual trimming allowing creditors to absorb the losses and 
recapitalize. In return for debt relief, bank debt was turned into tradable 'Brady bonds' backed by US treasuries as collateral, which reassured investors the restructured debt had real value. There were two broad types of Brady bonds, the par bonds with the same face value as the original debt but longer maturities and lower interest rates and the discount bonds with smaller face values but also shorter maturities and higher interest rates. The debt crisis did not stop with the Brady plan, however, this discussion is beyond the scope of this paper.

Meanwhile, debtor countries committed to a series of economic reforms as recommended by the Washington Consensus. The Brady plan was followed by hyperinflation first, then by draconian measures to stop it such as dollarization or currency boards as well as neoliberal reforms in developing economies. Those measures opened again the gates to western funds, only to lead to even more serious crisis and catastrophic defaults 10 year later. The sequel in Latin America was that growth was finally resumed by exporting commodities to the rising and industrializing East, essentially decoupling from a decaying and over-financed west.

From the Washington consensus' perspective, financial repression was understood as a situation in which government and Central Bank regulations tend to distort financial markets. These regulations mainly refer to reserve requirements on commercial banks, interest rates ceilings and compulsory credit allocations with or without subsidized interest rates. It was argued that theconsequences of financial repression constrained the growth of savings, investment and economic performance. Financial repression causes the flow of lendable funds to decrease in the formal financial sector, forcing potential investors to rely more on self-finance. It distorts credit allocation and causes inefficiencies in the productive sector. It encourages wealth holders to acquire physical assets instead of financial assets, causes capital flight and the process of self-finance is impaired. If the real yield of deposits is not attractive, firms cannot accumulate liquid assets to undertake investment.

Due to these arguments, the de-repression of the financial sector in LDCs (Singh, 2011) was heralded as a major breakthrough in economic policy. The financial liberalization reform was understood as a substantial reduction of government intervention in setting interest rates and allocating credit either by doing away entirely with the interventionist regime or by gradually reducing it. The objectives of financial liberalization were mainly to increase both the total level of savings and financial savings, with the aim of making the latter available for productive investment purposes. Market forces were supposed to maximize the availability of savings for investment as well as its allocative efficiency that is a 'logical consequence' of the neoclassical assumption that 'the market mechanism is the best instrument for an efficient allocation of resources' (Fitzgerald, 1993).

In the process of financial liberalization, one of the elements that became central to conduct the deregulation process further and that, eventually, turned out to be the main source of risks for the financial market, was that of the Financial Deepening Hypothesis (FDH). This approach argues that accumulation of financial assets at a pace faster than the accumulation of non-financial wealth will increase real savings. 'Measures to raise the real rate of return on financial assets, to reduce the variance of returns, and to improve the financial technology, along with allied non-financial areas, extend the saver's time horizons over both space and time' (Shaw, 1973, p.72). A positive and significant relationship between the size of the financial sector (measured by the ratio M3 to GDP) and the domestic rate of saving would be expected.

However the interpretation of the financial intermediation ratio (M3/GDP) in explaining real savings remains ambiguous and the difficulty with this variable lies in the explanation of the coefficient itself (Gupta, 1997). Under the lack of a proper regulation and supervision, the transformation of the banking economics in the financial system prompted the current financial system, which is now of public-policy attention everywhere as the flow of financial services need to be restored if economic growth is to be ignited again. This process was stimulated by both technology and a deregulation process implemented in the 1970s and 1980s, under the promise to take advantage from the opportunities through globalization and financial innovations.

Incidentally, the FDH was so intensively carried out in Latin America that led to a premature financialization of its economies that finding the way out in this conjuncture it requires to many adjustments elsewhere, not only in the financial system (see Palma 2009). Financialization is understood as the rise in size and dominance of the financial sector relative to non-financial sector, as well as the diversification towards financial activities in non-financial corporations. Actually, under such hypothesis LDCs decreed central bank freedom convinced that populist policymaking was the surest route to price stability and thus healthy economic growth. That is how LDCs adopted the holy writ in finance and economics that says monetary policy need to be free of political interferences and gave independence to central banks to focus only the control of prices. The growth of output will unfold as a simple after-effect.

\section{Market Failures, Macroeconomic Stability and Bank Supervision}

Because financial reforms in LDCs were inspired by the efficient capital market hypothesis (Palma, 2009), much of 
the failure of financial liberalization has been explained in the current literature as the result of macroeconomic instability and weak bank supervision (McKinnon, 1988; Villanueva and Mirakhor, 1990; Sundararajan and Baliño, 1990). This hypothesis assumes that financial market prices at any point of time fully reflect all available information, so that there cannot be an endogenous gap between market prices and fundamentals, let alone a bubble. It also assumes that the stock markets would always correct themselves automatically, because stock prices are supposed to be a random walk. In stock markets, there is no scope for profitable speculation, especially under risk neutrality, because smart market players would simply force stock prices to become rational by taking the other side of trades if prices begin to develop a pattern, as this is bound to have no substance.

It has been argued that certain characteristics were common to the relatively successful countries that liberalized their financial sector such as an appropriate macroeconomic framework that included goals of low inflation and low public deficit, ajudicious supervision of the banking system and a proper pace of deregulation. Countries in which these characteristics were present avoided sharp increases in interest rates, bankruptcies of financial institutions and loss of monetary control (Villanueva and Mirakhor, 1990). Singapore, South Korea and Taiwan were examples of these successful measures. The renewed debate on financial liberalization stated that the removal of credit and interest rates ceilings, rather than leading to a more efficient, healthy and dynamic financial system, will open up the possibility of greater market imperfections. Regulation imperfections are replaced by market imperfections such as asymmetric information and banking distress, which are implicit in the financial system.

\subsection{Imperfect Information}

In the credit market, borrowers have greater information about their own default risks than lenders do. Stiglitz and Weiss develop a model to show that this asymmetric information limits the rise in interest rates and the supply of loans (Gibson and Tsakalotos, 1991; and Villanueva and Mirakhor, 1990). In this analytical framework, the basic intuition of the modelstates that, while adequaterises in interest rate loans would producesizeable lending, further increases beyond a certain rate would promote lower lending activity by negatively altering the quality of borrowers in favor of those in the high risk category (Villanueva and Mirakhor, 1990). In this context, banks seek to maximize their profits (net of defaults). Very high interest rates might lower overall banks' returns by triggering two effects: firstly, credit worthy borrowers would be discouraged, and, secondly, borrowers would be induced to choose projects with a higher probability of default because projects with higher expected profits are riskier.

There is a limit to the real interest rate charged on loans beyond which the bank's expected return of such loan declines. This limit is not necessarily the same as the market clearing level (see figure 1). As observed in figure 1, the loan supply $L^{s}$ is a positive function of the real loan interest rate up to $r=r^{p}$. At this point banks maximize profits ( $\prod$ ). Profits are a function of the loan interest rate $(r)$ and of the probability of loan repayment $(\Theta)$ :

$$
\begin{gathered}
\Pi=\mathrm{f}(\mathrm{r}, \Theta) \mathrm{L} \\
\Delta \Pi / \delta \mathrm{r}>0, \text { if } \mathrm{r}<\mathrm{r}^{\mathrm{p}} \\
\Delta \Pi / \delta \mathrm{r}<0, \text { if } \mathrm{r}>\mathrm{r}^{\mathrm{p}} \\
\Delta \Pi / \delta \mathrm{r}=0, \text { if } r=r^{\mathrm{p}}
\end{gathered}
$$




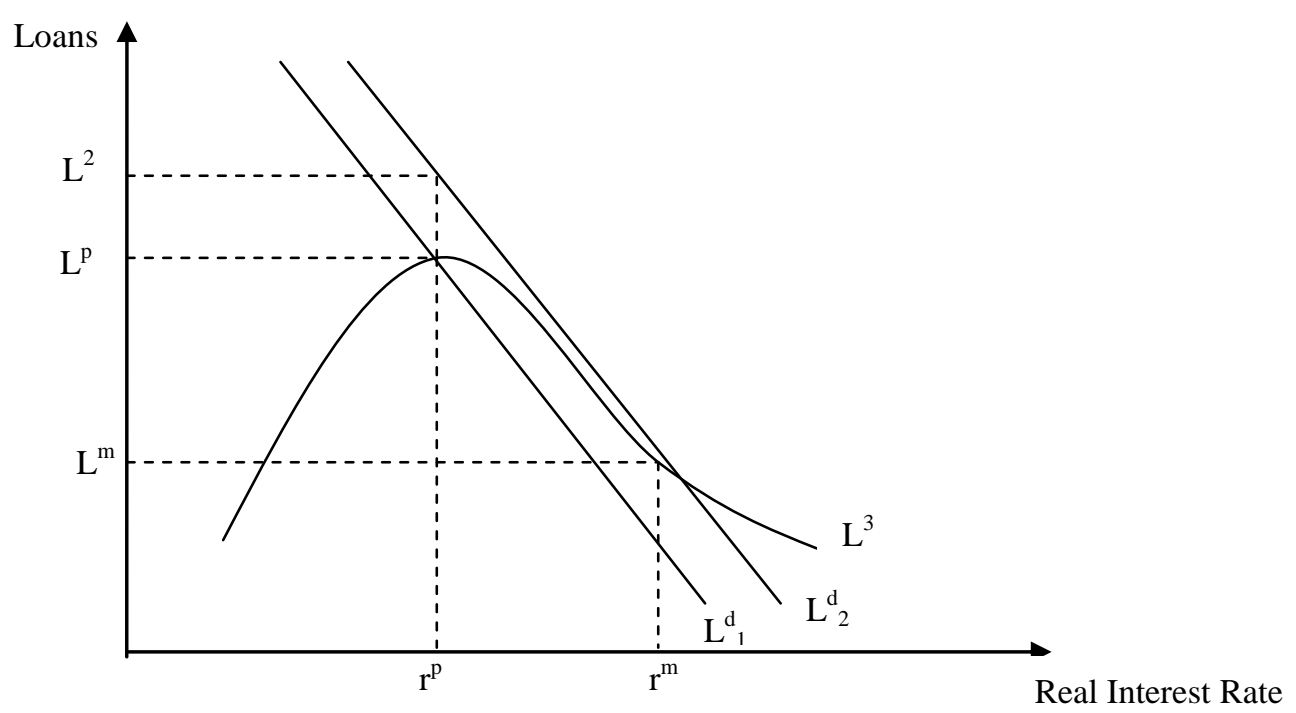

Figure 1. Market Clearing Level

The bank profit maximizing interest rate $r^{P}$ might coincide with the market clearing interest rate if loan demand is $L^{d}$. If, however, loan demand is higher, say $L_{2}^{d}$, the market clearing rate $r^{m}$ is higher than $r^{P}$. In this case, there will be an excess demand for loans equal to $\left(L_{2}^{d}-r^{P}\right)$. The profit maximizing interest rate $r^{P}$ is both 'optimal and efficient, because bank profits are at a maximum level and because risky borrowers are rationed out' (Villanueva and Mirakhor, 1990), even though it is below the market clearing level. 'It therefore appears that although credit rationing is a potentially adverse effect of financial repression, it is also a problem in liberalized financial markets' (Gibson and Tsakalotos, 1991).

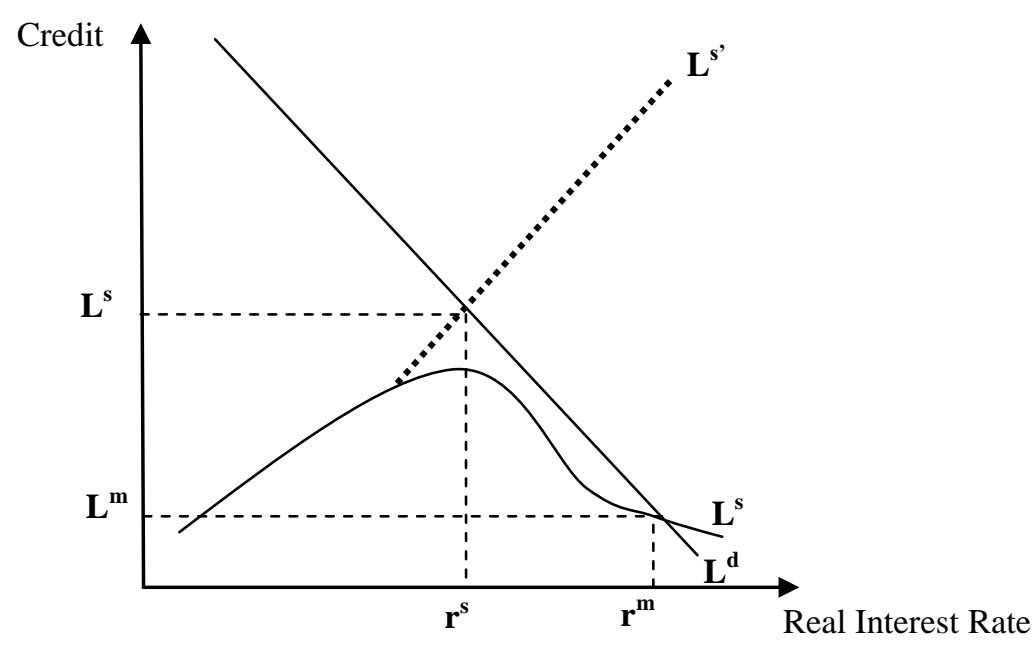

Figure 2. Market Failure in the Loan Market

The inverse U-shape of the supply of loans curve forces the market clearing interest rate $r^{m}$ (see figure 2) to be higher than the equilibrium rate, if banks do not consider the probability of default (as in the traditional literature). The supply of loans $L^{s^{\prime}}$ does not consider the probability of default by borrowers. In this case the real interest rate is lower $\left(r^{e}<r^{m}\right)$ and the amount of loans is higher $\left(L^{e}>L^{m}\right)$ at the market clearing level than if risk is considered in the loan supply function. Therefore market failures tend to constrain the supply of loans. Current studies (McKinnon, 1989; Villanueva and Mirakhor; 1990) do not mention the positive effect that high interest rates have on the productivity of investment projects, an argument that stands at the core of the financial liberalization models. It can be said that this 
renewed debate deals with a more operative view of the functioning of credit markets.

\subsection{Macroeconomic Stability and Bank Supervision}

Financial liberalization implies a structural reform of the banking system. This reform has led several developing countries to financial or banking crisis such as Argentina, Chile, Hong Kong, Malaysia, Mexico, Philippines, Thailand and Uruguay. The failure of banking deregulation has been associated with an unstable macroeconomic environment, banking distress and weak bank supervision. When dealing with developing economies, the term financial and banking systems are used indistinguishably because of the predominance of banks in the financial system.

Several stylized facts characterize a banking crisis, such as an intense demand for reserve money that could not be satisfied for all parties simultaneously in the short run and the fact that credits which must be liquidated. By the same token, a condition where borrowers, who in other situations were able to borrow without difficulty, become unable to borrow on any terms (a credit market collapse) as well as a forced sale of assets due to liability structures that are out of line with market determined asset values and the consequent further decline in assets values. A final stylized fact is the sharp reduction of the value of banks' assets, which results in insolvency of many banks (Sundararajan and Baliño, 1990).

Banking distress, which might cause a banking crisis, is defined as the situation where the advent of deposit insurance or implicit guarantees has allowed an insolvent financial institution to stay in business so long as its liquidity position remains manageable, mainly because of Central Bank assistance. Continuing banking distress perpetuates situations in which banks alone could not stand without the intervention of the Central Bank. If banks do not behave efficiently, distress prolongs resource misallocations that might precipitate distress conditions. This provides incentives for further risk taking. The decision of banks to undertake risky lending in the presence of government guaranties of deposit insurance is sometimes referred to as moralhazard. If banks are insured, or otherwise protected by the government, they undertake riskier loans than if they were not. The larger the share of risky loans, the bigger the possibility of default and of bank crisis.

Inadequate bank supervision can lead to the moral hazard problem. A dilemma arises if the IMF stand ready to lend huge sums to countries that get into trouble, those countries are less likely to adopt the difficult measures that may be needed to stay out of it. In addition, once a country has fallen victim to a financial crisis, the avoidable harm caused by failing to help can be enormous. The role of banking supervision is to develop procedures for both creditors and supervising institutions to monitor financial fragility and vulnerability to shock, identify the exposure to moral hazard, and formulate standards for evaluating the appropriateness of particular levels of risk exposure (Sundararajan and Baliño, 1990).

The combination of an unstable macroeconomic environment and inadequate bank supervision can lead to a financial crisis when the financial sector is liberalized. Then, loan interest rates might rise to excessively high and risky levels, especially in an inflationary environment. Moreover, the institutional structure of the banking system emerging from regulatory changes could lead to monopolistic or oligopolistic structures. A liberalization of interest rates implies a change of instruments for monetary control. It is argued that central banks might lack acceptable monetary policy controls to affect interest rates or might follow a laissez-faire approach leading to belief that national rates would mechanically meet to global rates (Sundararajan and Baliño, 1990). If reserve requirements are not eliminated, forcing banks to hold low-yield reserves or government securities, credit to the private sector can be tightened and cause excessively high real lending interest rates. Furthermore, it is argued that the supervisory institutions might not be prepared to deal with a more liberalized financial system.

Therefore, the administrative infrastructure must be adapted to deal more with bank solvency and credit risk than with organizing selective credit regulations and maintaining interest rates ceilings. The current literature sustains that 'sound financial policies, vigilant bank supervision and well designed prudential regulations would limit financial crisis and help reduce the vulnerability of a financial system to the vagaries of the macro-environment' (Sundararajan and Baliño, 1990).

In Chile, for example, the combination of high inflation, high real loan rates and inadequate bank supervision resulted in defaults of outstanding bank credits that led to the bankruptcy of virtually all of Chile's financial intermediaries in 1982. Macroeconomic stability is concerned with sustained steadiness in the internal price level, a necessary condition for attaining high real financial growth without undue risk of financial fright or failure (McKinnon, 1988). Concerning bank supervision, the literature suggests that governments should implement limits on ordinary loan and deposit's rates of interest to overcome banks' tendency to provide risky loans at high interest rates in the expectation of government intervention through deposit insurance (McKinnon, 1988b).

Macroeconomic stability also implies a low and controlled public sector deficit. If financial liberalization takes place 
when the public sector's internal debt is high and rising, the rise in real interest rates will increase the public deficit. This could lead to a vicious circle of rising public deficits and macroeconomic instability (Gibson and Tsakalotos, 1991). High interest rates paid on the domestic debt will cause inflation if money is created to pay the interest charges. The failure of financial liberalization in several countries has been attributed to market failures and to inadequate bank supervision. Under unstable macroeconomic conditions, firms will probably need to borrow credits no matter that the loan interest rate is, for instance to refinance maturing debts. When moral hazard is present and bank supervision is weak, banks are willing to lend at high and risky interest rates, because the government would rescue them from bankruptcy. Therefore, the policy to follow is, first, to liberalize the financial sector under a stable macroeconomic environment and second, to establish an adequate bank supervision scheme.

\section{Conclusion}

Assuming the causality between financial development and economic growth, this essay has portrayed the main theoretical models considered in the first generation of structural reforms induced by the international financial institutions and other parties involved in the strategies. This topic intended to leave behind the debt crisis in the 1980's: the Neo-classical, on the one hand, and the Post-Keynesian, on the other hand. Given the fact that the Neo-classical models were implemented in almost all the developing economies, this essay describes the models of Mckinnon (1973) and Shaw (1973), in both of which financial liberalization is considered as a necessary condition for economic development, based on the classical assumption that prior saving was necessary to finance investment and economic growth.

The analysis of financial liberalization theories shows that credit markets are subject to imperfections that set limits to the loan rate of interest and to the amount of credit supplied. Therefore the hypothesis that increased savings and investment are a consequence of the liberalization of the financial system has been severely weakened. Furthermore, imperfect information and weak bank supervision do justify a government's intervention in the financial system to prevent a banking crisis. Independent central banks, such as it was argued, would prevent a return to the rampant inflation of the 1970s. And up until the credit crunch, the consensus of Washington seemed right. Inflation had stayed pegged at or near historically low levels, while economic growth remained remarkably stable. But the financial crisis changed all that.

It has became obvious that those same independent central bankers, captains of finance and the public stewards of the financial system, as a whole had failed to grasp the building-up of risk and missed out 'to see to come' the biggest private sector debt disorder in history, encouraged through moral hazard wholesale financial sector recklessness and fuelled sequential asset bubbles. Beside such a failure, all the culture of deregulation that believed wrongly that markets would always self-correct is in tatters as Chang (2010) put it forward.

There is no evidence that market forces will operate more efficiently than regulated financial systems because markets forces have to be supervised by an entity. Usually this entity is the Central Bank. Past and quite recent experiences from different countries show that the absence of regulation of the financial system leads to financial distress and to financial crisis under weak supervision and unstable macroeconomic scenario. In this sense, government intervention is more than justified in order to prevent a financial crisis that might trigger or aggravate an overall economic crisis in the near future.

\section{Acknowledgements}

Benjamin García-Páez was a visiting scholar in the University of Cambridge sponsored by the DGAPA-UNAM. We are grateful to Professors Ajit Singh and Ha-Joon Chang at the Development Studies Committee of the University of Cambridge for suggestions and to the anonymous reviewers for their constructive comments. We are however responsible for the views expressed and the errors which might remain.

\section{References}

Buffie, E. F. (1984). Financial Repression, the New Structuralist and Stabilization Policy in Semi-Industrialized Economies. Journal of Development Economics, 14. http://dx.doi.org/10.1016/0304-3878(84)90061-0

Burkett, P., \& Dutt, A. K. (1991). Interest Rate Policy, Effective Demand and Growth in LDC's. International Review of Applied Economics, 5(2), 1991.

Chang, H. J. (2000). The Moral of Moral hazard: Untangling the Asian Crisis. World Development, 28(4), 775-778. http://dx.doi.org/10.1016/S0305-750X(99)00152-7

Chang, H. J. (2010). 23 Things They Don't Tell You About Capitalism, Allen Lane.

Davidson, P. (1996). Finance, Funding, Saving and Investment. Journal of Post-Keynesian Economics, IX, 1986.

Dutt, A. K. (1990). Interest Rate Policy in LDCs: A Post-Keynesian View. Journal of Post-Keynesian Economics, 
13(2), 1990-1991.

Fitzgerald, E. V. K. (1993). The Macroeconomics of Development Finance. Macmillan.

Gibson, H., \& Tsakalotos, E. (1991). Economic Theory and the Limits to Financial Liberalization: Domestic Financial Liberalizations in Greece, Portugal and Spain. Unpublished, 1991.

Mckinnon, R. I. (1973). Money and Capital in Economic Development. The Brookings Institution, Washington, D.C.

Palma, J. G. (2010). The Revenge of the Market on the Rentiers: Why Neo-liberal reports of the end of History Turned Out to be Premature. Cambridge Journal of Economics, 2009, 829-369.

Palma, J. G. (2010). Why has productivity Growth Stagnated in Most Latin American Countries since the neo-liberal reforms? CWPE 1030.

Patrick, H. (1996). Financial Development and Economic Growth in Underdeveloped Countries. Economic Development and Cultural Change, XIV, January 1966.

Rathbone, J. P. (2010). Eurozone can learn grim Latin Lessons, FT, December 22.

Shaw, E. S. (1973). Financial Deepening in Economic Development. Oxford University Press.

Singh, A. (2011). Financial Liberalization, Stock Markets and Economic Development Lecture Subject 1. M.PhilDevelopment Studies, March.

Sundararajan, V., \& Baliño, T. (1990). Issues in Recent Banking Crisis in Developing Countries. IMF Working Papers, IMF 1990.

Thirlwall, A. P. (1989). Growth and Development with Special Reference to Developing Economies. Macmillan.

Van Wijnbergen, S. (1983). Interest Rate Management in LDCs. Journal of Monetary Economics, II.

Villanueva, D., \& Mirakhor, A. (1990). Interest Rate Policies, Stabilization, and Bank Supervision in Developing Countries: Strategies for Financial Reforms, IMF Working Paper, IMF 1990.

World Bank. (1989). World Development Report 1989: Financial Systems and Development. 